http://doi.org/10.35784/iapgos.1608

\title{
OVERVIEW OF BROADBAND INFORMATION SYSTEMS ARCHITECTURE FOR CRISIS MANAGEMENT
}

\author{
Jacek Wilk-Jakubowski \\ Kielce University of Technology, Department of Information Systems, Kielce, Poland
}

Abstract. Many risks as a result of accidents, catastrophes and natural disasters can contribute to crisis situation, which according to the definition means a set of circumstances, both external and internal, that affect a given system through changes. Crisis situations are usually the result of natural disasters. Where such phenomena occur, it is important to ensure communication both at regional and national level. This is particularly important in areas affected by disasters caused by force majeure, such as earthquakes. The main aim of the article is to provide an overview of the architecture of contemporary information systems including satellite links, in order to present information on the potential possibilities of their use in the case of crisis situations.

Keywords: information systems engineering, web services, satellite systems, crisis management, VSAT

\section{PRZEGLĄD ARCHITEKTURY SZEROKOPASMOWYCH SYSTEMÓW INFORMACYJNYCH DO CELÓW ZARZĄDZANIA KRYZYSOWEGO}

\begin{abstract}
Streszczenie. Wiele zagrożeń wynikających z wypadków, katastrof czy klęsk żywiołowych może przyczynić się do powstania sytuacji kryzysowych, przez które zgodnie z definicja rozumie się zbiór okoliczności, zarówno zewnętrznych, jak $i$ wewnętrznych, majacych wptyw na dany system poprzez zaistniałe zmiany. Sytuacje kryzysowe sa zazwyczaj wynikiem klęsk żywiołowych. W przypadku wystapienia takich zjawisk ważne jest zapewnienie odpowiedniej komunikacji zarówno na poziomie regionalnym, jak $i$ krajowym. Jest to szczególnie istotne na obszarach dotkniętych kleskami żywiołowymi spowodowanymi siła wyższa, takimi jak trzęsienia ziemi. Głównym celem niniejszego artykułu jest przegląd architektury wspótczesnych systemów informacyjnych, z uwzględnieniem sieci satelitarnych, w celu przedstawienia informacji na temat potencjalnych możliwości ich wykorzystania na potrzeby komunikacji w sytuacjach kryzysowych.
\end{abstract}

Słowa kluczowe: inżynieria systemów informacyjnych, usługi internetowe, systemy satelitarne, zarządzanie kryzysowe, VSAT

\section{Introduction}

The Institute of Crisis Management from the US distinguishes four groups of sources of crises: (1) random factors (e.g. earthquakes, floods); (2) technical problems (e.g. accidents in production facilities); (3) human errors (e.g. communication disasters); and (4) wrong decisions at management level [2]. Such unfavorable situations may affect the operation of a person, an institution or even the entire country. For instance in the case of damage to typical terrestrial technical infrastructure, the use of wireless links (including satellite links) very often becomes the only possible way to ensure communication. Otherwise, it threatens to deepen the crisis situation [19]. Technical applications and the ability to access various types of networks play a significant role, which becomes possible with available mobile devices. Since a crisis situation has a negative impact on people's safety, it is important to use countermeasures $[11,21]$. Information systems engineering allows to obtain, collect, process and distribute information by means of electronic equipment $[10,22,24]$. Along with access to the Internet, it is possible to access the content published there, as well as to use many services, such as [3, 4, 6]: (1) e-mail; (2) FTP; (3) discussion groups; (4) streaming services. In addition, the Internet allows the presentation of various data (mainly all text, audio and video) and, as a leading service, influences the availability of multimedia services in the IT environment. Thus, they include access to many other services provided over the Internet as a part of one comprehensive service, which is covered by flexible network architecture.

Satellites play an important role in providing global communication for almost decades. Along with the increase in data transmission speed in terrestrial networks, an increase in the speed offered on satellite links has been noted [27]. The reports of the Federal Communications Commission (FCC) in the US covering information on the actual speeds obtained in individual broadband communication systems have included Internet access as a satellite service since 2013 [16]. In the light of FCC reports the obtained transmission speed is often higher than the declared value (the difference is $40 \%$ for $90 \%$ of users during peak hours). In this respect this service can be ranked first in the US broadband Internet ranking [17]. What's more, the service of satellite Internet access provides the smallest speed changes depending on the time of day, with the achieved speed being at least $30 \%$ higher than the declared one and the average upload speed is $61 \%$ higher than the declared one. Therefore, access to broadband Internet using satellites can be a good option for stable Internet access due to the achieved parameters better than the parameters of traditional terrestrial links and reliability (investments in failover and redundant switching in VSAT systems cause that some networks offer $99.9921 \%$ reliability). It is worth noting that in the case of systems using satellites located in geostationary orbit, continuity of service is determined by the earth station. Only when the level of the received signal meets the assumed quality criteria (exceeds the set level for a given percentage of time per year and the worst month), it is possible to receive stable signals. While, according to the FCC report, the use of satellite services involves high system reliability and the lifetime of the satellites often exceeds the time specified in the technical specifications, it becomes difficult to repair the satellite's on-board equipment in the event of failure, which must also be calculated for the operation of the satellite system. Satellites are therefore designed with multiple layers of redundancy and backup systems. The quality levels achieved are equal to or even better than the military specifications for the manufacture, launch and exploitation of space satellites. In summary, the use of satellite systems via the connection of remote networks to the primary backbone network and cellular infrastructures allows for transmission with $99 \%$ reliability and therefore seems to be a good way to ensure communication in case of a crisis situations.

\section{Selected aspects of the use of satellite links to ensure communication}

In the $21^{\text {st }}$ century in particular satellites are used to extend the range of operation of cable or radio networks providing access to the Internet, as well as mobile phone networks, when the range of traditional networks is insufficient. Undoubted advantages of satellite systems are: (1) ability to build global networks; (2) ability to communicate with fixed and mobile terminals; and (3) flexible provision of multiple services. Moreover, the following advantages can be indicated: (1) long-life of a satellite (usually at least 15 years); (2) low influence of the Doppler effect, because the relative speed of the satellite decreases with the increase in the orbit height; and (3) relatively constant reception level.

From a practical point of view, the use of satellite networks has also some disadvantages. One example is the propagation delay on the Earth-to-Satellite and Satellite-to-Earth links, which 
makes it difficult to carry out any kind of real-time transmission. Therefore, many techniques are used to reduce the value of this delay. In practice propagation delay in corporate networks is several hundred ms, because the single jump time between the satellite and the Earth is equal to from $120 \mathrm{~ms}$ to $140 \mathrm{~ms}$. For comparison, the delay in terrestrial networks is significantly lower and is equal to about $5 \mathrm{~ms}$ [27]. Thus, the delay caused by jumps: Earth-Satellite and Satellite-Earth for both receivers is significant reducing the use of the physical channel [9]. This has an impact especially on real-time voice communication. In addition, the propagation delay limits the use of systems for interactive sessions without enhancements when users constantly enter data (e.g. remote login), as well as any applications in which small packets of data are generated in response.

On the other hand, the use of satellite networks has many benefits (the cheapest way to build regional, national and intercontinental links; the possibility to build links in locations where there are a lack of adequate technical infrastructure, e.g. in sparsely populated areas, seas or oceans; no environmental degradation due to the need to build traditional communication links and many others). In the $21^{\text {st }}$ century satellites are used to transmit Internet traffic wherever the use of traditional terrestrial lines is impossible or uneconomic. Apart from the need to ensure uninterrupted communication in the event of a crisis situation, satellite links can find many other applications. Offshore oil companies can be exemplified by using satellite data networks to communicate directly with platform headquarters and offshore oil tankers. There is a practical justification for using satellite networks to build networks for many entities, such as: (1) oil, mining and gas companies; (2) public entities (including government and military agencies); (3) research centers (including schools); (4) medical centers (including telemedicine); (5) enterprises offering remote surveillance systems and disaster prevention measures; (6) banks; (7) hotels; (8) shops and other entities with branches in many countries. Reliable data transmission is a key part of a computer or communication network in times of distributed systems. Such communication can be implemented in a TCP/IP network using many protocols associated with an IP multicasting. Undoubtedly, the advantage is the fact that many protocols may be used, such as: FTP, HTTP, NNTP, POP, SMTP and many others [9].

\section{Architecture review of satellite broadband information systems}

Many factors should be taken into account in the design of satellite systems, such as: (1) system reliability; (2) service continuity; and (3) declared signal quality parameters. Many VSAT terminals should have access to specified resources in a given percentage of time per year and per worst month. As previously indicated, satellites have a wide spectrum of applications which may also apply in domestic and corporate use. As the examples we can point out: (1) Small-Office-Home-Office (SOHO), e.g. Internet Direct to Home (DTH) systems and services dedicated to small and medium-sized enterprises (SME); (2) construction of combined local area networks (LANs); and (3) cooperation of VSATs with ground-based systems to increase network coverage and the range of services offered. However, in practical application, satellite networks should support a wide range of high-speed applications which require high quality productivity with proper use of satellite resources. To provide broadband IT services, including communications, in the event of a crisis situation, many operators satellites can be used [12], an example is the first HTS (High Throughput Satellite) in Europe and the Mediterranean Sea with significant capacity and efficiency $[13,18]$. Many computer tools are designed to simulate the parameters of this Ka-Sat satellite $[14,15]$.

The architecture of broadband systems offering access to multiple satellite services involves the appropriate construction of the on-board satellite equipment modules. The two main methods for handling the data stream are listed: (1) bent pipe and (2) on-board processing and switching. The choice of a specific technology depends on the purpose of the satellite system. There are one-way communication systems, which only allow to receive signals, e.g. dedicated to sending information to users located in the area of natural disaster, as well as two-way communication systems, which apart from reception allow to send data. In the event of crisis situation, access to the Internet as a leading service seems to be particularly important. The ability to use small, often portable, ground-based VSAT terminals is also a key issue. Depending on the methods for handling the data stream, radio wave propagation is accompanied by different signal degradation, which in turn is reflected in the technical infrastructure of systems. The attenuation of the signal as the basic component of signal degradation (an additional component is noise increase) is strictly dependent on among other things, the frequency of radio waves, as well as atmospheric conditions accompanying radio wave propagation $[25,26,28]$. Thus the correct reception is dependent on the proper implementation of technical equipment [27, 29]. The use of signal retransmission systems involves a lack of signal regeneration (Fig. 1) and is therefore characterized by significant propagation attenuation (including primary attenuation due to the considerable distance between the earth station and the satellite). Antennae links are controlled by means of dedicated links and monitoring system. On the other hand, the advantage of systems allowing retransmission of data is to ensure transparent data transmission, which involves possible modification of signal structure on the Earth and translates into building new protocols without interfering with the occupied band [30].

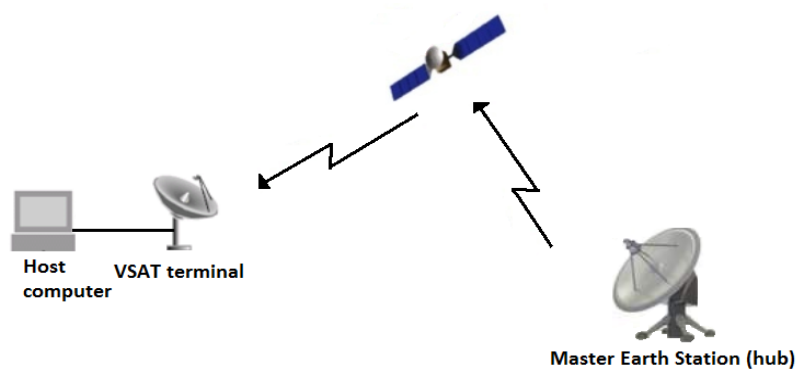

Fig. 1. Bent pipe communication with the use of a VSAT terminal

A different approach is the use of signal processing and switching techniques using satellite's on-board equipment (Fig. 2). Compared to bent pipe, the obtained link budget is much better. Such systems are mainly used for the construction of geostationary access systems, where the broadcasting (group) nature is important.

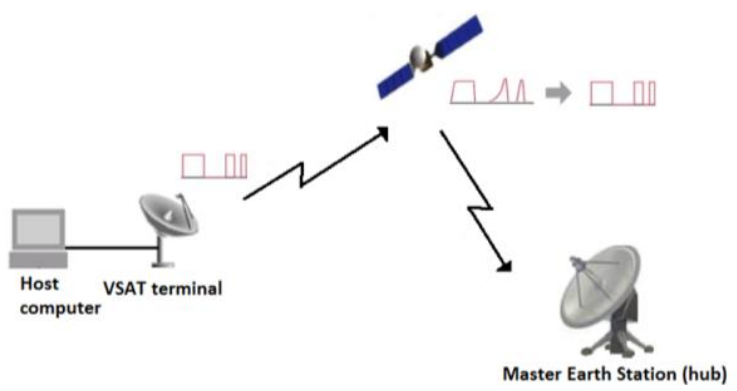

Fig. 2. Regenerative communication with the use of a VSAT terminal

As the satellite's on-board equipment processes data coming from the channels, the control of the antenna beams (spatial commutation) is possible, so that the signal can be directed to a particular beam, as shown in Fig. 3. From a technical point of view a control data can be used to build in space both switched and packet transmission networks in which the antennae have dynamically controlled beams $[5,7,8]$. In systems allowing regeneration of the signal, the link budget may be less favorable, and thus the satellite board may transmit less power. Moreover, terminal antennae may have smaller aperture due to signal regeneration, which in turn compensates greater signal degradation due to smaller antenna aperture. 


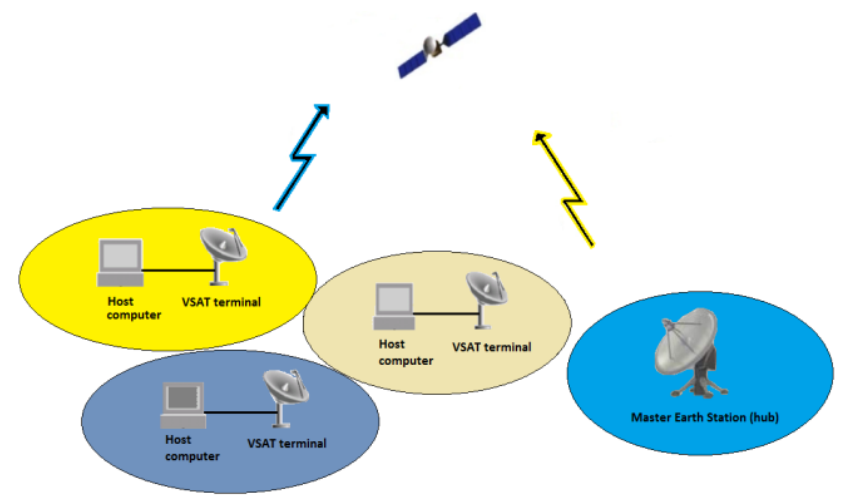

Fig. 3. On-board processing and switching communication with the use of a VSAT terminal

This is particularly important for the installation of mobile receiving terminals in the case of emergency situations. They are easy to install because of small size of the antennae. On the other hand, taking into account the technical issues, the inconvenience is the fact that the link is adjusted to the protocol, and thus the transmission is non-transparent. Therefore, it is not possible to modify the signal structures on the Earth, which makes it impossible to create new transmission protocols without interfering with the occupied band. The disadvantage of such systems is also significant delays in signal propagation (Fig. 4).

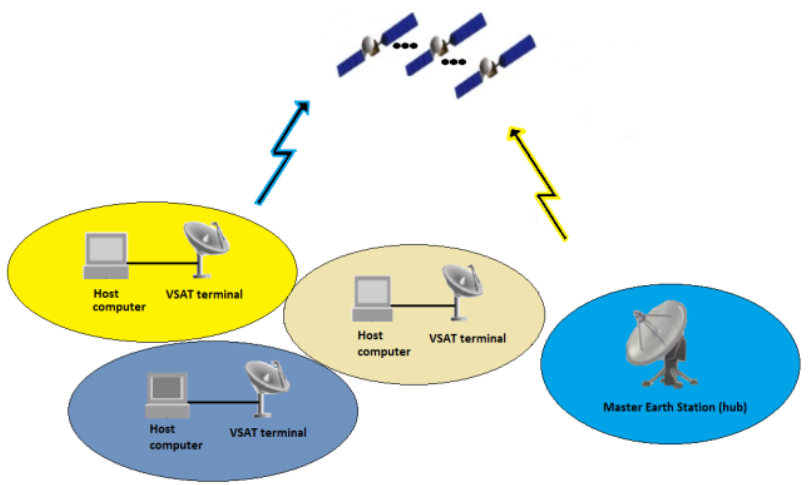

Fig. 4. On-board processing and switching communication with the use of a VSAT terminal and links between satellites

Satellite systems can serve not only as access networks, but also as access and backbone networks. If the system serves as access network, the signals from the terminal after reception by satellite are transmitted to a ground station connected to terrestrial infrastructure. The signals are sent directly to the receiver (web server) or close to it, and then via the terrestrial or satellite access network are sent to the destination. If the satellite system serves as an access and backbone network, the signals from the terminal after receiving via satellite are sent via satellite links to the satellite used by the receiver, or to the gateway which is connected to the terrestrial backbone network [30,31]. As the examples can be indicated: (1) virtual private networks; (2) local area networks; (3) remote connection to the Internet backbone network; and (4) video conferences (e.g. with point-to-multipoint networks). Among other things, it becomes possible: (1) network caching; (2) creation of user groups (e.g. units responsible for crisis management); (3) implementation of digital audio/video transmissions; (4) real-time database updates, etc. These solutions are usually used by governmental institutions (e.g. rapid network building in the event of crisis situation), companies with branches in many countries or continents, as well as Internet and satellite service providers to ensure long distance data transmission. As has been mentioned information can be sent simultaneously by satellite to a group of users (multicast) as long as the receiving terminals are within the coverage of selected area. Taking into account the above factors, it is possible to develop satellite characteristics depending on the appropriate purpose. For instance any point-topoint applications, in addition to network resources, help mitigate congestion and increase customer ability to manage services [23].

Figure 5 contains an illustration of the link reference for a satellite network serving as a transport network. Base stations as the satellite gateways (SGs) are points of contact with the access networks or IP distribution networks.

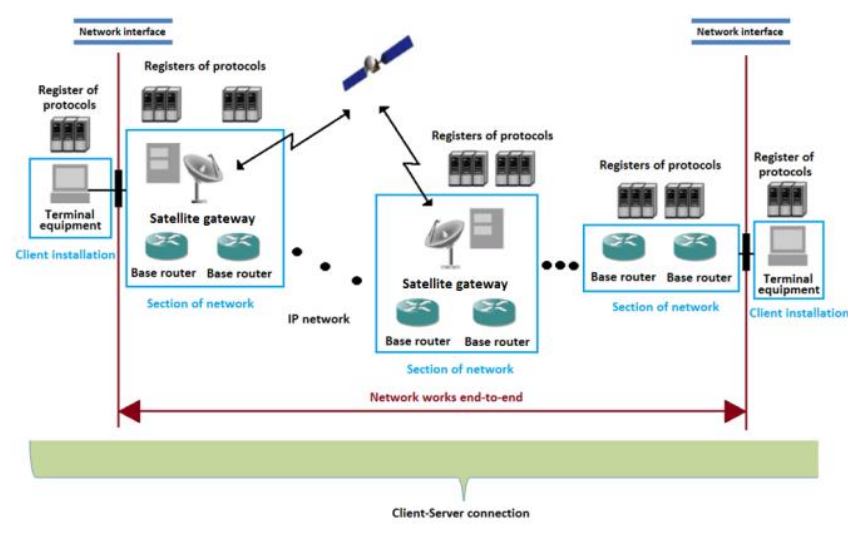

Fig. 5. Hypothetical reference link to the satellite network serving as a transport network

By the use of the IP network, which is crucial to ensure communication with an edge network, as a distribution network, it becomes possible to transmit data between the receiver and the transmitter of the terrestrial network section (Fig. 6). It is important to choose the appropriate base station (SG), which is closest to the source terminal (ST) and closest to the destination terminal (DT). It reduces undesirable signal deterioration due to long distances transmission over the IP network. The ST terminal, which is used for data transmission, is connected to the base station SG via the IP network or leased line. The satellite link can serve as the access network and distribution and access network. It is possible to use retransmission satellites for the access network. Wired or radio links can be used to build a return channel, and the satellite part as a receiver [1]. When a terminal allowing both reception and data transmission is used, then the terrestrial technical infrastructure is not included [30].

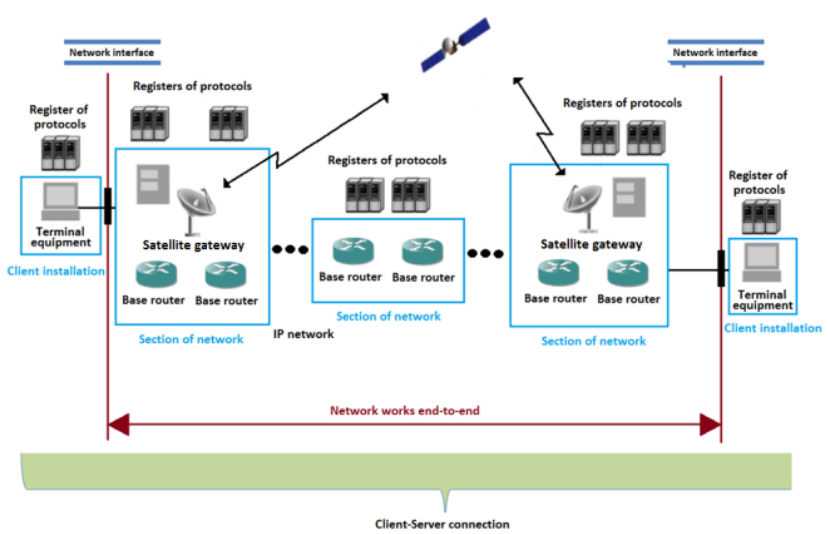

Fig. 6. Hypothetical reference link to the satellite network serving as a data distribution network in an edge network

In practice satellite networks provide access to many IT services and Internet access can be a leading service for a large number of end users. It enables the use of many tools and web applications (Fig. 7). Due to the asymmetric nature of links, the return channel from the terminal station usually sends small traffic to the service distribution point. Because the data transmission speed is not constant, it is characterized by frequent changes. Ground links can also be used for data transmission. One of the solutions for bandwidth optimization in satellite terminals is to use techniques of multiplying access to the radio channel [30]. 


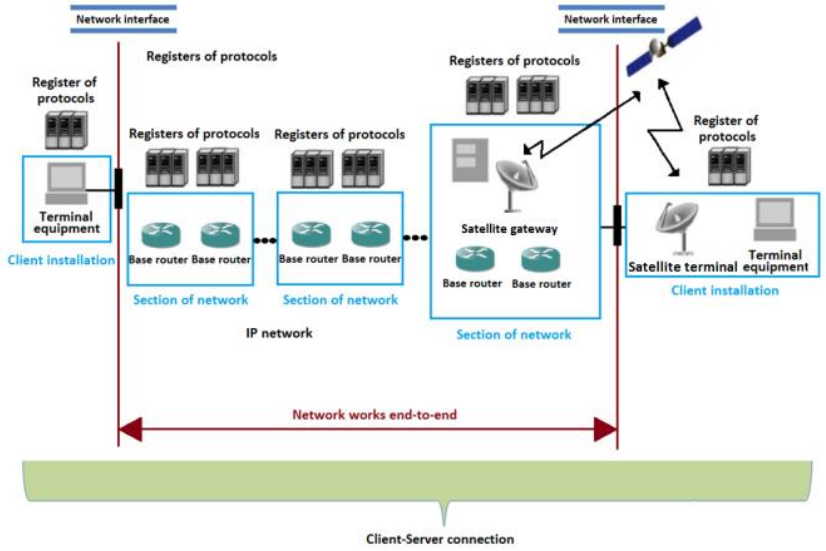

Fig. 7. Hypothetical reference link to the satellite network serving as an Internet access network

Group transmission (multicast) allows data to be transferred economically to VSAT terminals which are used as receivers. The exemplification can be streaming data and providing multimedia services using the intranet or Internet services. One of the advantages is that there is no need to collect data when providing services in real time. Both terrestrial and satellite links can be used to provide a return channel. Networks operating in PMP (Point-to-MultiPoint) mode are required to meet data link layer requirements. Higher layers are responsible for proper reception of the signal. In the case of networks designed for group and broadcast transmission, the signals are retransmitted using satellites and then received by terrestrial receiving terminals.

\section{Conclusions}

Satellite communication as a complex form of communication provides users the global network services with many multimedia services and is crucial in the case of damage to traditional ground technical infrastructure. As the main benefits of using satellite systems can be mentioned [20]: (1) the quickest, cheapest and least invasive way to build regional, intercontinental and global networks; (2) the ability to use links wherever this is not possible using traditional links because of: (2a) the lack of terrestrial technical infrastructure; (2b) the lack of coverage of traditional means of communication (cable and radio links); or (3) it is not economically viable; (2) easy installation and reconfiguration of the system; (3) continuous operation in crisis situations when terrestrial technical infrastructure is damaged, e.g. due to an earthquake; (4) the ability to work in many modes (including point-tomultipoint mode). Real-time network monitoring, synchronization and management are also possible. There is the ability to build local networks of connections or Internet access (for instance routers can be carried by the movements received by the satellite and sent to the network, which allows for fast data transmission in local networks). Moreover terminals can be easily moved and with the use of VSAT technology it is possible to build backup links, in addition to basic links, e.g. when satellites are the only way to ensure connectivity.

\section{References}

[1] Baras J.S., Corson S., Papademetriou S., Secka I., Suphasindhu N.: Fas asymmetric Internet over wireless satellite-terrestrial networks. CA, Monterey 1997.

[2] Barton R.M.: Crisis Management. Oxford Press Publishers, Oxford 1993

[3] Bem D.J., Więckowski T.W., Zieliński R.J.: Radiowe systemy szerokopasmowego dostępu. Krajowe Sympozjum Telekomunikacji, Bydgoszcz 2001.

[4] Bem D.J., Więckowski T.W., Zieliński R.J.: Satelitarne systemy dostępowe 2. Przegląd Telekomunikacyjny i Wiadomości Telekomunikacyjne 8, 2001, 22-30.

[5] Bem D.J., Zieliński R.J.: Bezprzewodowa transmisja pakietowa. V Krajowa Konferencja Radiodyfuzji i Radiokomunikacji (KKRR 2000), Poznań 2000.
[6] Bem D.J., Zieliński R.J.: Satelitarne systemy dostępowe. Przegląd Telekomunikacyjny i Wiadomości Telekomunikacyjne 8/9, 2000, 593-601.

[7] Bem D.J., Zieliński R.J.: Transmisja pakietowa 1. Infotel 9, 2000, 34-36.

[8] Bem D.J., Zieliński R.J.: Transmisja pakietowa 2. Infotel 10, 2000, 20-26.

[9] Choi H-K., Qadan O., Sala D., Limb J.O., Meyers J.: Interactive Web Service via Satellite to the Home. IEEE Communications Magazine 39(3), 2001, 182190.

[10] Collin S.M.H., Głowiński C.: Słownik komputerów i Internetu. Wydawnictwo Wilga, Warszawa 1999.

[11] Eguchi S., Kameda S., Kuroda K., Oguma H., Sasanuma M., Suematsu N.: Multi-mode portable VSAT for disaster-resilient wireless networks. Asia Pacific Microwave Conference (APMC 2014), Sendai 2014.

[12] Euroconsult: 2018 Edition, https://www.eutelsat.com/files/live/sites/eutelsatinternet/files/PDF/investors/2017-

18/Eutelsat_Communications_Reference_Document_2017-18.pdf (available: 10.02.2019).

[13] Eutelsat - Ka-Sat, https://www.eutelsat.com/sites/eutelsatinternet/home/satellites/9-east.html\#ka-sat (available: 05.06.2016)

[14] Eutelsat - Services,

https://services.eutelsat.fr/deploy_Sorbet_SSO/pages/changeGraphParameters.d o (available: 30.04.2019).

[15] Eutelsat - Services,

https://services.eutelsat.fr/deploy_Sorbet_SSO/pages/displaySelectAELocation. do (available: 30.04 .2019 ).

[16] FCC Office of Engineering and Technology i Consumer and Governmental Affairs Bureau, http://www.fcc.gov. (available: 30.04.2019).

[17] Gajewski M.: Internet satelitarny przoduje na liście usług szerokopasmowych w USA, https://www.chip.pl/2013/04/internet-satelitarny-przoduje-na-liscieuslug-szerokopasmowych-w-usa (available: 25.04.2013).

[18] iDirect: High Throughput Satellites (HTS), http://52.3.84.67/Company/HighThroughput-Satellites.aspx (available: 04.06.2016)

[19] Księga Komunikacji Kryzysowej 2017: Postawy zarządzania informacją w kryzysie. Rządowe Centrum Bezpieczeństwa, Warszawa 2017.

[20] Pontano B.A.: Linkway TM for 21 st century military communications. MILCOM 2000 Proceedings. 21st Century Military Communications. Architectures and Technologies for Information Superiority (Cat. No. 00CH37155), CA, Los Angeles 2000.

[21] Sasanuma M., Uchiyama H., Nagoya T., Furukawa M., Motohisa T.: Research and development of very small aperture terminals (VSAT) that can be installed by easy operation during disasters - Issues and the solutions for implementing simple and easy installation of VSAT earth station. IEICE 112(440), 2013, 1-3.

[22] Słownik języka polskiego: Teleinformatyka, https://sjp.pwn.pl/sjp/teleinformatyka;2577777.html (available: 23.01.2016).

[23] Souto G., Stevenson J.: Technical features of the @ INTELSAT Internet product suite. IEE Colloquium on Current Developments in Intelsat (Ref. No: 1997/367), London 1997.

[24] Wilk-Jakubowski G.: Wpływ technologii informatyczno-komunikacyjnych na funkcjonowanie współczesnych społeczeństw. Grabiński T. (ed.): Rola informatyki w naukach ekonomicznych i społecznych. Innowacje i implikacje interdyscyplinarne. Wydawnictwo Wyższej Szkoły Handlowej im. B. Markowskiego w Kielcach, Kielce 2011

[25] Wilk-Jakubowski J.Ł.: Measuring Rain Rates Exceeding the Polish Average by $0.01 \%$. Polish Journal of Environmental Studies 27(1), 2018, 383-390.

[26] Wilk-Jakubowski J.Ł.: Predicting Satellite System Signal Degradation due to Rain in the Frequency Range of 1 to $25 \mathrm{GHz}$. Polish Journal of Environmental Studies 27(1)/2018, 391-396.

[27] Wilk-Jakubowski J.Ł.: Propagacja fal radiowych w łączności satelitarnej. Radiowaves propagation in satellite communications systems. Wydawnictwo Politechniki Świętokrzyskiej, Kielce 2018.

[28] Wilk-Jakubowski J.Ł.: Total Signal Degradation of Polish 26-50 GHz Satellite Systems Due to Rain. Polish Journal of Environmental Studies 27(1)/2018, 397 402

[29] Wilk-Jakubowski J.Ł.: Wpływ wybranych parametrów technicznych systemu na odbiór fal radiowych. Informatyka, Automatyka, Pomiary w Gospodarce i Ochronie Środowiska 3/2018, 65-68.

[30] Zieliński R.J.: Satelitarne sieci teleinformatyczne. Wydawnictwa NaukowoTechniczne, Warszawa 2009

[31] Zielinski R. J.: Nowe techniki w systemach VSAT, http://absta.pl/ryszard-jzieliskinowe-techniki-w-systemach-vsat.html (available: 25.07.2019).

\section{Ph.D. Jacek Lukasz Wilk-Jakubowski}

e-mail: j.wilk@tu.kielce.p

Kielce University of Technology, Ph.D. (technical) Faculty of Electrical Engineering, Automatic Control and Computer Science, Department of Information Systems.

Research interests: teleinformatic systems, data transmission, signal processing, electrical engineering, wave propagation.

http://orcid.org/0000-0003-1275-948X

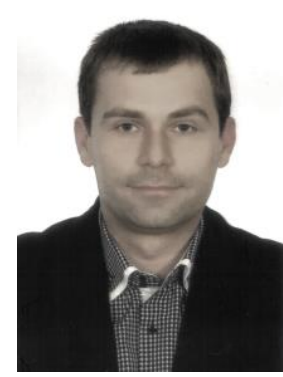

otrzymano/received: 01.04.2020 